\title{
Contingent Fit-Misfit and Business Unit Performance (A Review Based on the Perspective of the Congruency Hypothesis)
}

\author{
Diana Zuhroh
}

Economic And Business Faculty University of Merdeka Malang

Jl. Terusan Raya Dieng No. 62-62 Malang, 65145, Indonesia

\section{Info Article}

Article History:

Approved:

Publishe:

Keywords:

Fit Low Cost; Fit Differentiation; Misfit Low Cost; Misfit $D$ ifferentiation; Performance

ISSN (print) : 2598-7763 ISSN (online): 2598-7771

$\triangle$ Corresponding Author:

Diana Zuhroh:

Tel. /Fax. 085876877955

E-mail: diana.zuhro@unmer.ac.id

\section{Abtract}

This study was designed to obtain the influence of contingent fit and misfit on business unit performances in the perspective of the congruency hypothesis. Fit is reached when the company implements a low-cost strategy, practices traditional management accounting and uses automation information technology. Conversely, the company implements differentiation strategy tend to practices strategic management accounting and enabler information technology. This study was a survey method using questionnaires, and regression was used to analyze the data. This study concluded that contingent fit has a positive influence on the performance of customer, internal process, and learning/growth for business units in Fit group. However, the influence of contingent misfit on the performance of financial, customer, internal process and learning/ growth was inconsistent. According to the Congruency Hypothesis, when the three subsystems are in fit, the configuration to be formed is a straight or almost straight line, which means, the level of elements in subsystems is equal. For these business units, the contingent fit has a positive influence on performance. Conversely, when the three elements are in misfit, the configuration to be formed is not a straight line. This study failed to prove the influence of contingent misfit on the performance of financial, customer, internal process and learning/growth.

Citation: Zuhro, D., (2019). Contingent Fit-Misfit and Business Unit Performance (A Review Based on the Perspective of the Congruency Hypothesis) AFRE Accounting and Financial Review, 2 (1)

\begin{abstract}
Abstraks
Penelitian ini bertujuan untuk memperoleh bukti empiris tentang pengaruh keselarasan kontinjensi terhadap kinerja unit bisnis yang ditinjau dengan perspektif Congruency Hypothesis. Selaras dicapai jika perusahaan menerapkan strategi biaya rendah, akuntansi manajemen tradisional, dan sistem teknologi informasi pengotomatisasi. Sebaliknya, perusahaan yang menerapkan strategi diferensiasi cenderung menerapkan akuntansi manajemen stratejik dan teknologi informasi pemampu. Penelitian ini menggunakan metode survey dengan kuesioner dan untuk olah data digunakan regresi. Hasil olah data menunjukkan, keselarasan kontinjensi yang dicapai oleh bisnis unit yang berada pada grup fit berpengaruh terhadap kinerja keuangan, konsumen, proses internal, dan pertumbuhan/pembelajaran. Sesuai dengan konsep Congruency Hypothesis, jika ketiga elemen subsistem dalam kondisi fit maka akan terbentuk garis lurus. Kondisi ini terbukti berpengaruh terhadap kinerja unit bisnis. Sebaliknya jika ketiga elemen subsistem dalam kondisi tidak selaras, konfigurasi yang terbentuk tidak berupa garis lurus. Penelitian ini tidak dapat membuktikan pengaruh ketidakselarasan kontinjensi terhadap kinerja keuangan, konsumen, proses internal, dan pertumbuhan/pembelajaran.
\end{abstract}

JEL Classification: L11, L25

DOI: https://doi.org/10.26905/afr.v2i1.3170 


\section{INTRODUCTION}

The use of information technology in the manufacturing sector is increasingly high. Its use has led to new and digital-based business models, not only in the production process, but also in the entire value chain to achieve the highest efficiency (kominfo.go.id). An example, the results of a study show, 44 percent of manufacturing industries plan to activate Just-in-Time (JIT) notifications for their customers. The application of this technology is mostly aimed at high-tech industries $(48 \%)$, pharmaceuticals $(40 \%)$, automotive $(35 \%)$, and food \& beverages (36\%) (www.kabarbisnis, 2017).

The use of information technology generally is to implement the strategy, and the next goal is to achieve competitive advantage. Companies need to formulate a competitive strategy (Jogiyanto, 2005: 32-33), and for this, the system of information technology system (ITS) is needed to supports efficiency and strategic decision making. In addition, management accounting system (MAS), which plays an important role in providing financial and nonfinancial information is also required to support operational and strategic decision making in accordance with the management level. Currently believed, it is unlikely that the accounting was applied without the use of information technology (Dechow et al., 2007:628). Even, the relationship between management accounting and information technology seems to be getting tighter (Pervan and Dropulic, (2019); Pedro, Simona and Martinez (2018); Vasarhelyi, and Brad Tuttle, (2016); Warren et al, (2015))

In recent years, studies concerning with linking of the strategy with environmental variables, technology, organizational structures and management control systems within the framework of contingency theory has been the focus of studies related to the business organization (Chenhall, 2007:164). The concept of alignment or fit between information technology (IT) and business strategy has been discussed for many years, and strategic alignment is seemed crucial in increasing firm performance (Ismail and King, 2007). The role of management accounting system in supporting the formulation, implementation and change of strategy is the next focus (Langfield- Smith, 2007:755).

In accordance with the contingency theory, companies that achieve fit between the three variables: competitive strategy, MAS and ITS will achieve a better competitive advantage, which in turn will drive the achievement of better performance. According Bhimani (2006: 75), fit concept of the three variables can be explained figure 1 .

When these conditions can be achieved it means that there has been a Fit (alignment) between strategic subsystems with operational subsystem, which in turn, will improve the quality of decisions taken by the management, and the next result is organizational performance will also be better.

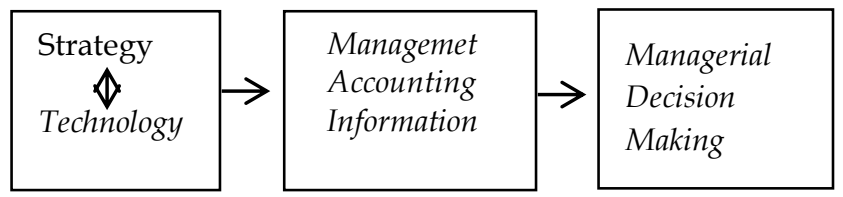

Figure 1. Likage of Strategy, Management Accounting System, and Information Technology Systems.

Business-level strategy according to Porter (1993) is widely used to achieve competitive advantage, consisting of low cost and differentiation. Companies that implement differentiation strategy requires a rapid response to changes in consumer tastes, therefore, it must always be actively monitor the market. These conditions lead companies require financial and non-financial information, and Strategic MAS is considered capable in providing such information. The necessary information technology system is information technology system with the characteristics as enabler (Venkatraman, 1994).

Conversely, company that is implementing low cost strategy generally emphasize the processes being take place is running in a timely and efficient (Baines and Smith, 2003; Jermias and Ghani, 2004). Low cost strategy requires MAS that provides information with greater emphasis on the financial aspect, and the ITS that are considered able to support the practice of traditional MAS is ITS as automation. The role of this system is to automate the recording of transactions that were previously done manually.

Contingency theory assumes that contingent fit between competitive strategy with contextual variables will lead the organization to achieve good performance and vice versa. "Good fit means enhanced performance, while poor fit implies diminished performance" (Chenhall, 2007:164). In relation to the performance, according to the researchers, the Balanced Scorecard is one measure that is considered more representative to integrate non-financial and financial measures within a framework that is explicitly linked to strategy (Chenhall, 2006:107; Langfield-Smith,2006:252-253; Langfiel-Smith, 2007: 768). Research by Zuhroh (2015) concluded, the performance of the differentiation business unit that achieve a fit is better than the business unit 
with the same strategy, but in the misfit condition.

The results of the research by Luftman and

Tal Ben-Zvi (2011) concluded that the alignment between ITS with the processes that take place within a business organization becomes a concern of researchers. Research on the relationship between MAS with ITS undertaken by Atkins (1994) concluded that information technology which is able to support the practice of MAS have a positive effect on the improvement of the performance of the company. However, some researchers have also found that the alignment does not affect the performance, for example: Luftman and Brier (1999), Kholeif et al. (2008), Hoque (2004) and Morton and $\mathrm{Hu}$ (2008), Mouritsen (2007:634).

The study of the relationship between strategy and management accounting generally has produced consistent conclusions, for example from research conducted by Hyvonen (2008) and Malmi and Sandelin (2016). However, previous studies related to the fit between strategy, management accounting systems, and information technology systems still showed inconsistent results. The linkages between information technology and management accounting are often uncertain, even surprising, and misleading, therefore further research is needed to develop insights into this relationship. (Dechow et al, 2007; Hoque, 2004; Kholeif et al, 2008; Morton and $\mathrm{Hu}, 2008$ ). Subsequent research conducted by Quattrone (2016) that the effects of the digital revolution on management accounting and decision-making are still unclear.

Referring to the proposition by Chenhall (2007: 174) and is associated with the concept of IT development by Venkatraman (1994) that: according to the contingency theory, the system or subsystem in the company considered to achieve fit if there is a fit or alignment of the application of competitive strategy, practice of MAS, and the use of ITS with the following configuration: 1) Fit Low Cost: when a company implement strategy tend to low-cost, use MAS tend to traditional, and practice ITS tend to automation; 2) Fit Differentiation: when a company implement strategy tend to differentiation, practice MA tend to strategic and use ITS tend to enabler. Thus, the company is considered to be in misfit if two kinds of configurations is not formed.

This study was primarily designed to obtain empirical evidence that: fit that achieved by the business unit includes in Fit Group has a positive influence on the performance of the business unit. The research objectives are: 1) To analyze the business units in the Fit group: Whether the suitability has been achieved by the business unit has a positive influence on financial performance, customers, internal processes and growth/learning. in business units have a negative influence on financial performance, customers, internal processes, and growth/learning.

Because of the role of information technology is greater in current business practice, then the results of this study is expected will improve the relevance of theory with practice of accounting and business in general.

\section{HYPOTHESES DEVELOPMENT}

\section{The Concept of Fit and Misfit in the Contingency Theory}

Contingency Theory states that the success of an organization is determined by the ability of the organization to adapt environmental factors that motivated by the need for organizations to survive (Burrel and Morgan, 1979:165). Organization is a series of subsystems and each subsystem function is managed to achieve the overall success of the organization. The subsystems within the organization, according Burrel and Morgan (1979: 165) is considered similar to a continuum line and has the characteristics as described by Burrell and Morgan (1979: 171-175) in figure 3. As also explained by Gerdin and Greve (2004), the fit which give a positive impact on the better performance is a result of a more or less appropriate combination between the context and structure. There are 2 approaches of fit in contingency theory, namely: Cartesian and Configuration (Gerdin and Greve, 2004). The definition of fit according to Cartesian approach is: "fit is combination of the levels of the contingency and structure that produce higher performance" (Donaldson, 2001:185) as shown in Figure 2 (Donaldson, 2001:191). The figure provides an insight: fit will be achieved if the contingent and structural factors in a company are at the same "level" and, if otherwise, it will produce misfit (Donaldson, 2001:211). Research about misfit conducted by Gani and Jermias (2015), Burton et al (2002), and Grescow (1989) concluded, misfit negatively affect performance, both financial and non-financial.

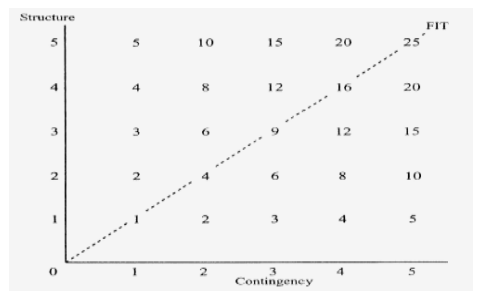

Figure 1. Level of the Fit and Performance 


\section{The Value of Contingent Fit and Misfit}

One important aspect of contingency theory is the interdependence of the task, that is, to what extent activities is inter-related, both vertically and horizontally (Donaldson, 2001: 19). Research conducted by Hayes (1977) concluded, interdependencies among subunits has an effect on the performance of the business unit. Meanwhile, according to Jermias and Gani (2004) fit is the conformity (proper match) among the subsystems in a system. For each subsystem can be given a score or value. The higher the value of a subsystem, the greater the contribution of the subsystem for the functioning of overall the system. The fit value is the average value of all the subsystems that make up a system. The higher the fit value means the greater the role of a subsystem in a company, which would then be the greater the potential for such systems to support the improvement of the performance of the company (Jermias and Gani, 2004). In the Cartesian view, research on contingency theory should be able to show that higher degree of fit is assosiated with the higher performance" (Gerdin and Greve, 2004). Based on this concept, the higher the misfit can also be associated with the lower performance.

\section{Subsystems in the Organization}

According to Porter, there are two generic strategies used by the company: differentiation and low cost. As noted by Chenhall (2003, 2007), the most important thing to be studied at this time with regard to contingency theory is an important role of the competitive strategy and its relationship with other variables, especially technology and management accounting systems. Otley (1982) also states that environmental change, technology, and the choice of competitive strategy will determine the need for information, which in turn will affect the design of accounting information systems, management information systems, organizational structure and control systems.

In response to the changing environment, business policies can be viewed from two perspectives: strategic versus tactical, or, competitive advantage versus the efficient management (Nishimura, 2005: 227). According to Nishimura (2005: 228-229) it will determine the need for MAS: traditional or strategic. MAS traditional emphasizes on the financial aspects for monitoring the efficiency and productivity improvement, while, strategic MAS emphasizes on the financial and non-financial information in a balanced manner. Nishimura (2005: 228) details the techniques of management accounting, are: 1) Traditional Management Accounting Practices: ratio analysis, standard costing, budgetary control, variance analysis, cost-volumeprofit analysis, inventory modeling, opportunity cost accounting, and performance evaluation; 2) Integrated or Strategic Management Accounting practice: activity based costing system, balancedscorecard, back-flush accounting, target costing, value chain analysis, life cycle costing and quality costing system.

The major role of information technology (IT) in an organization is related to: efficiency, effectiveness, communication, collaboration, and competition (Jogiyanto, 2003: 18). According to Venkatraman (1994), the role of IT has evolved from the original focus on increasing efficiency through automation into the role as enabler to create and maintain flexibility in the network. According to Hemmatsfar (2010), key factors of strategic information systems today are: Decision Support System (DSS), nterprise Resource Planning (ERP), and Database systems with the "data mining".

In the current contingency study, the variable performance is directed on the measurement of performance that consists of financial and nonfinancial which is based on the concept of the Balanced Scorecard (Langfield-Smith, 2007: 768). This because of the balanced scorecard is an engineered of accounting information that directly linked to the strategy (Langfield-Smith, 2007: 773 ). The performance in the Balanced Scorecard concept consists of four perspectives (Kaplan and Norton, 1996: 25-29).

Furthermore, Burrel and Morgan (1979: 176) describes the concept of fit among the sub-systems within an organization in the congruency hypothesis, as shown in Figure 3. that: "... a necessary condition for the effectiveness of an organization in meeting the demands of its environment is that the relationships between subsystem characteristics be congruent..." (Burrel and Morgan, 1979:176). According to the figure, the extreme conditions of fit is the relationship between subsystem in line A and B, while the condition of "intermediate" is in line C. The condition of misfit occur if the relationship among the subsystems are in line D. Also from the figure above, when the subsystems are in fit condition, which means they are at the same level, according to the concept of "the congruency hypothesis" the configuration that is formed is a straight line. 


\begin{tabular}{|c|}
\hline ENVIRONMENT \\
\hline $\begin{array}{c}\text { ORGANISATIONAL } \\
\text { SUBSYSTEMS }\end{array}$ \\
\hline Strategic \\
Operational \\
Human \\
Managerial \\
\hline
\end{tabular}
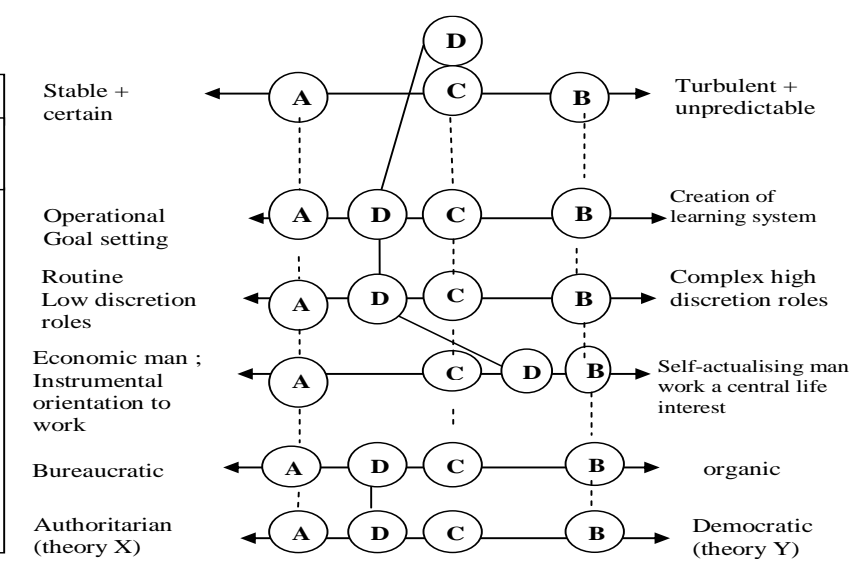

Figure 2. The Fit Model in the Contingency Theory

Based on these descriptions, the research hypothesis is structured as follows:

$\mathrm{H}_{1}$ : Contingent fit has a positive influence on the performance of financial, customer, internal processes, and growth / learning in business units that are in the group Fit.

$\mathrm{H}_{2}$ : Contingent misfit has a negative influence on the performance of financial, customer, internal processes, and growth / learning in business units that are in the group Misfit.

\section{DATA AND METHODS}

This study was conducted in East Java with the unit of analysis are business units of large manufacturing enterprises.

\section{Variables of the Research and operational defini-} tion of variables

\section{Variabel Independent:}

\section{Contingent Fit (X1).}

Contingent Fit, is the implementation of competitive strategy, practice of management accounting systems and the use of information technology systems in a business unit that is in accordance with the contingency theory with the following configurations: 1) Fit Low Cost, business unit that implements strategy tend to low cost, practices MAS tend to traditional, and uses ITS tend to Automation (figure 3).

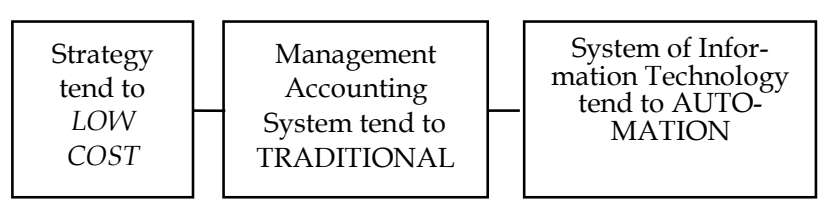

Figure 3. Strategy tend to Low Cost
2) Fit Differentition is business unit that impelements strategy tend to differentiation, practices MAS tend to strategic and uses ITS tend to enabler (figure 4).

\begin{tabular}{|c|c|c|}
\hline $\begin{array}{c}\text { Strategy } \\
\text { tend to } \\
\text { DIFFER- } \\
\text { ENTIA- } \\
\text { TION }\end{array}$ & $\begin{array}{c}\text { Management } \\
\text { Accounting Sys- } \\
\text { tem tend to } \\
\text { STRATEGIC }\end{array}$ \\
\end{tabular}

Figure 4. Strategy tend to Differentiation

\section{Contingent Misfit (X2)}

Contingent Misfit is the implementation of competitive strategy, practice of MAS, and the use of ITS in a business unit that is not in accordance with the contingency theory with the following configurations.

\section{Dependent Variable:}

Y1: the performance of financial, customer, internal process and learning/growth of Fit group.

Y2: the performance of financial, customer, internal process and learning/growth of Misfit group.

\section{Variable Measurement}

The Contingent Fit and Misfit is measured using the value of Contingent Fit and Misfit (figure $5)$. The measurement of independent variable $(X)$ was done through the following stages: 1) Respondents were asked to answer questions about the elements of fit consisting of: implementation of competitive strategy, practices of MAS and the use of SIT as presented in Table 2. At the time of the tabulation of the data, in order to obtain the corresponding calculation for the purpose of separating groups of respondents, the reverse scale used, and the details are: 1) Strategy Differentiation: never 
implemented (1)-implemented intensively (5); 2) Strategy Low Cost: never implemented (5)-implemented intensively (1); 3) Strategic of MAS: never practiced (1)-practiced intensively (5); 4) Traditionalof MAS: never practiced (5)- practiced intensively
$(1)$; 5) Enabler of SIT: never used (1)-used intensively (5); 6) Automation of SIT: never used (5)used intensively (1).

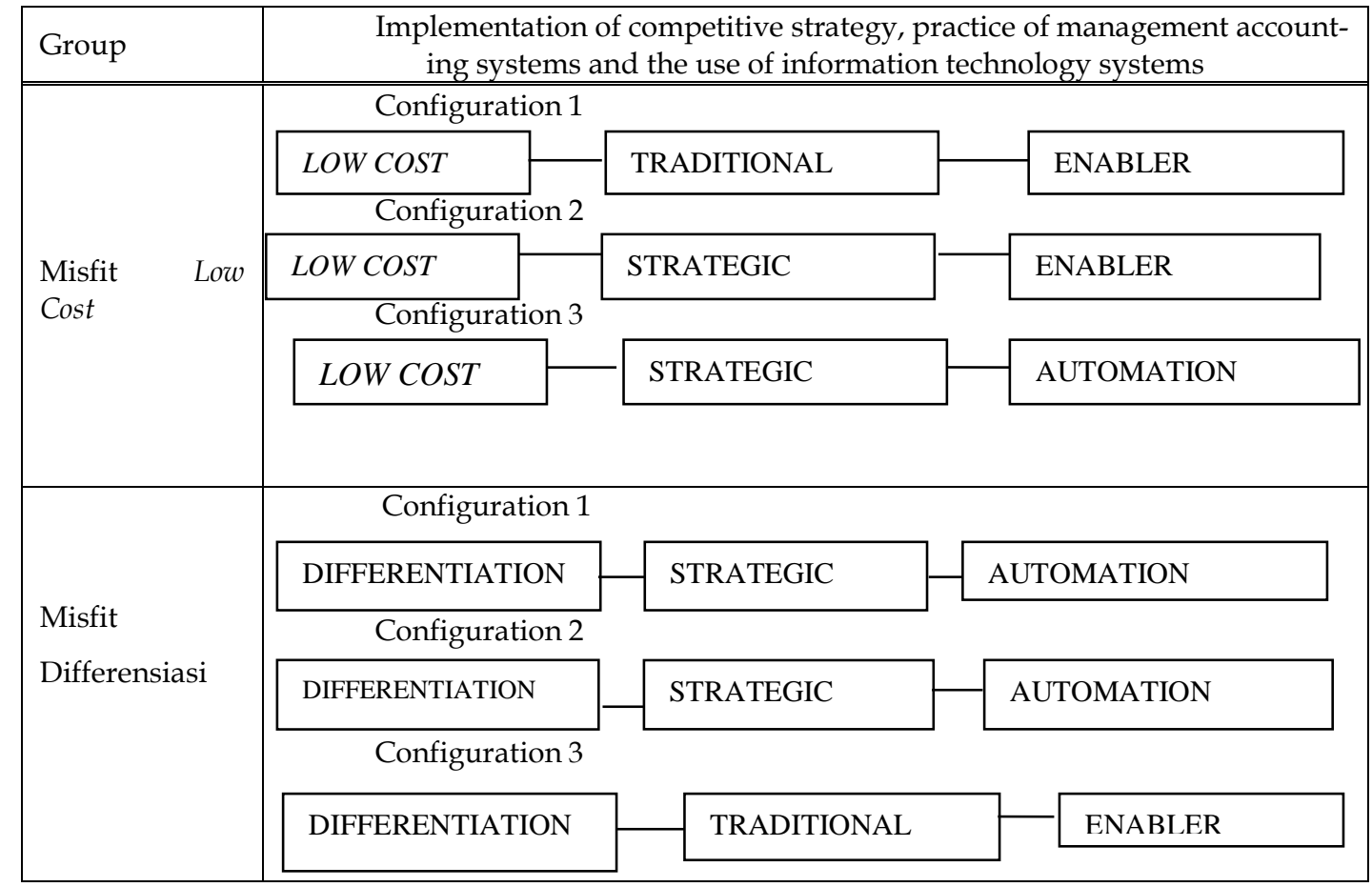

Figure 5. Configuration of Misfit Group

Respondents' answers were tabulated and then identifying the business units that implementing strategy Low Cost and Differentiation, practicing MAS Traditional and Strategic and using SIT Automation and Enabler done using the following procedure (Jermias and Gani, 2005): 1) Competitive Strategy: if the average score of respondents answer is higher than the mean, the business unit was considered implementing strategy tend to differentiation. If the average score of respondents is lower than the mean, the business unit is considered implementing strategy tend to low cost; 2) The same procedure used to determine the practice of MAS tend to strategic or traditional as well as use of ITS tend to automation or enabler; 3) Based on the tabulation at stage 1 and 2, the recapitulation to classify respondents into groups Fit Low Cost, Fit Differentiation, Misfit Low Cost and Misfit Differentiation were made; 4) Calculation of the value of fit and misfit for each business unit was performed using the formula (Jermias and Gani, 2004; 2005):

$$
F i t_{j}=\frac{1}{N} \sum_{i=1}^{N} \mathrm{X}_{\mathrm{ij}}
$$

Where: Fit ${ }_{j}=$ The total value of contingent fit in a business unit $\mathrm{j}$. $\mathrm{X}_{\mathrm{ij}}=$ contingent-fit contribution from contextual variablei for entity $\mathrm{j}, \mathrm{N}=$ the number of contextual variables.

Table 2. Model of Measurement of Fit's Elements

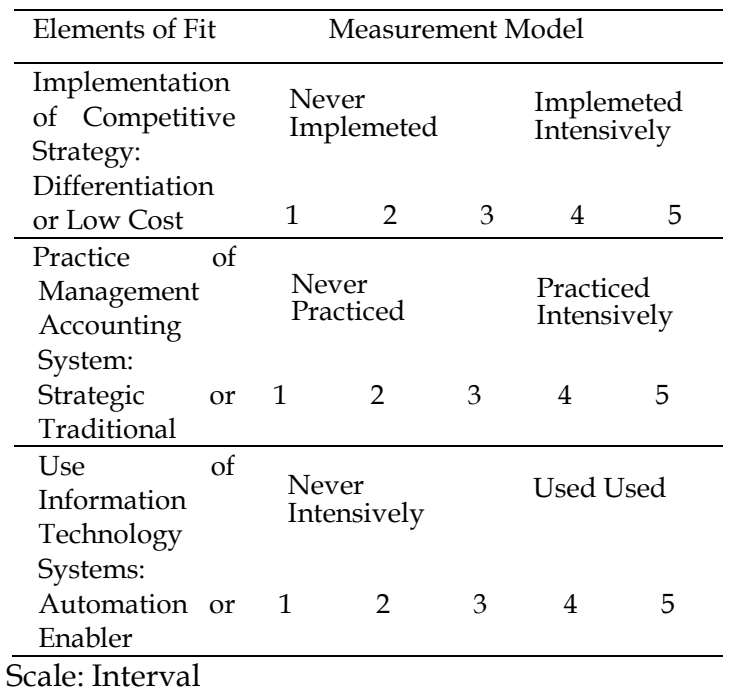


Performance is measured from respondents perceptions on financial performance, customer, internal processes and learning/ growth by giving the value and write it in the available column (Table 3). Performance of the financial perspective using target as the basis of measurement because in general, the financial performance is determined based on certain financial targets. Performance for customers, internal processes and learning/growth using the "plan" as a basis of measurement because in general these elements are not "targeted" but "planned" in the work plan or annual plan.

Table 3. Variable Performance Measurement Model

\begin{tabular}{lll}
\hline Element of Performance & Measurement \\
\hline Financial & If : The last year target was reached $100 \%$ or more, then the value is 100, \\
& $\bullet \quad$ The last year target was reached $50 \%$, then the value is $50 ;$ \\
Customer & If : The last year target was not achieved, then the value is 0. \\
Internal Process Learning/ & - The last year planning was reached $100 \%$ or more, then the value is 100. \\
Growth & - The last year planning was reached $50 \%$, then the value is 50. \\
&
\end{tabular}

\section{Research Instrument}

The research instrument was a questionnaire and the questions were: 1) Questions for differentiation strategy concerning with policies that lead to create unique products and services for consumers. While the questions for strategy low cost related to the policy directed to achieve efficiency and determination the selling price is cheap; 2) Questions for the practice of strategic MAS consists of: ABC system, target costing, quality cost, life cycle costing and balanced scorecard. While for the practice of traditional MAS, the questions were about: ratio analysis, variance analysis, strndard costing system, budgeting, Break Event Point (BEP) analysis and Economic Order Quantity (EOQ); 3) Questions for the use of enabler ITS systems were: data base, ecommerce, ERP and internet-based IDI. Questions for the use of automation ITS were: use of spredsheed, computer program for accounting, phone based EDI and the use of internet for communicating with customer.

Most of the questions have been used by previous researchers as the validity and reliability that have been tested. Questions for competitive strategy adopted from Jermias and Gani (2004, 2005), Baines and Smith (2003), Kaplan and Norton (1996), and questions for Management Accounting System adoptd from Nishimura (2005) and Jermias and Gani (2005). Questions about SIT taken from Jogiyanto (2003) with modified questions from Duh et al. (2006) and Hemmatfar (2010). Separation of ITS in the level of automation and enabler is based on the concept of Venkatraman (1994). Questions for the variable of performance of the company entirely refers to the concept of Balanced Scorecard (Hansen and Mowen, 2007). tirely refers to the concept of Balanced Scorecard (Hansen and Mowen, 2007).

\section{Population, Sample and Determination of the Sample}

Population of this research is business unit of a large manufacturing company or single business in East Java. Large manufacturing company is a manufacturing company that employs more than 100 people (www.bps.go.id), and there were $478 \mathrm{com}$ panies (Ministry of Industry, 2010). Respondents were business unit manager or finance manager business unit (CFO / Chief Financial Officer) or the internal auditor of the business unit.

\section{Data Processing}

The data was processed by the following stages: 1) Checking the completeness of answers, followed by the tabulation into Excel program; 2) Grouping of business units into groups Fit Low Cost and Differentiation, Misfit Low Cost and Differentiation; 3) The Value of Fit computation for group Fit and Misfit using the procedure as described in the previous section.

\section{Hipothesis Testing}

To test the hypothesis, the regression analysis on each performance using equations pre-sented:

$$
\begin{aligned}
& \text { Fit } \rightarrow Y_{i}=\beta_{0}+\beta_{1} X_{1}+\varepsilon \\
& \text { Mislift } \rightarrow Y_{2}=\beta_{0}+\beta_{2} X_{2}+\varepsilon
\end{aligned}
$$

With: $\mathrm{Y}_{1}$ :The performance of financial, customer, internal process and learning/growth of Fit group; 
$\mathrm{Y}_{2}$ : The performance of financial, customer, internal process and learning/growth of Misfit group; $\mathrm{X}_{1}$ : The value of Contingent Fit for group Fit; $X_{2}$ : The value of Contingent Misfit for group Misfit $\beta_{0}$ : intercept; $\beta_{1}$ : regression coefficient for the Value of Fit Variable; $\beta_{2}$ : regression coefficient for the Value of Misfit Variable; and $\varepsilon$ : error

Test of assumptions. Test of regression assumption in this study is normality of error using Kolmogorov-Smirnov test due to the number of samples are more than 50 .

\section{RESULT}

\section{Instrument Test and the Assumption of Regresion}

A total of 90 questionnaires were returned and feasible for further processing. Results of data processing using SPSS obtained: Pearson Correlation value is greater than 0.5 and a significance value of 0.00 so that the items of questions in the questionnaire are valid (Sekaran, 2003: 207). Cronbach's Alpha value for all elements of the Fit are greater than 0.7, so it can be stated that the questions are reliable (Hair et al., 2010: 125). Based on the test of the assumption using the KolmogorovSmirnov test (Hair et al., 2010: 73), the result is: sig Kolmogorov-Smirnov test for the entire group is greater than 0.05 so it can be concluded that Ho failed to reject, thus distribution of error is normal.

\section{Descriptive Analysis}

The results of data processing shows, the highest mean for the implementation of the strategy tend to differentiation is "On Time Delivery" (4.49), and for the implementation of the strategy tend to low cost is "Efficient Use of Assets" (4.23), it indicates that these policy are considered important. Relating to the practice of MAS tend to strategic, the highest mean is the use of "Product Life Cycle Cost Report" (4.06), while for MAS tend to traditional, the highest mean is "Budget" (4.37). Associated with the use of ITS as enabler, the mean for the intensity of the use of "Data Warehouse" is also highest (4.42), while the use of ITS tend to automation is the use of the "Program Office" (4.41). With regard to financial performance, highest mean is "Sales Growth", while for the customer performance is "Customers Retention". Relating with internal processes performance, the highest mean is "Timeliness of Delivery", while for learning and growth performance is "Employee Benefits".

\section{Grouping of Business Units Based on Fit.}

Based on variable measurement that have been presented in the previous section, there were four groups, namely: Fit Low Cost (17 business units), Fit Differentiation (20 business units), Misfit Low Cost (21 Business Units), and Misfit Differentiation (32 business units).

\section{Results of Regression Test}

The results of regression is presented in Table 4. From the table, the obtained result is: as hypothesized, the value of contingent fit affect the performance of Customer, Internal Process, and Learning/Growth, except financial performance, at $\alpha=5 \%$ for Fit group. The coefficient $(\beta)$ for Fit group is also positive, which means, if there is an increased of fit, then there is potential for Performance improvements to be achieved. The fact of this study is: for Fit group, the fit of the application of competitive strategy, MAS practices and the use of ITS is an important factor to achieve better customer, internal process, and learning/growth performance. Meanwhile, for business units in the Misfit group, the overall coefficient (beta) obtained doesn't match with the prediction although the probability value obtained is significant at $a=5 \%$. Tus, this study does not prove that misfit negatively affects the performance of financial, customer, internal process, and learning/growth.

Table 4. Regression Test Result for Each Group and Type Performance

\begin{tabular}{|c|c|c|c|c|c|c|c|c|}
\hline \multirow{2}{*}{ Group. } & \multicolumn{5}{|c|}{ Financial Performance } & \multicolumn{3}{|c|}{ Customer Performance } \\
\hline & t-stat. & $\beta_{1}$ & Prediction & Prob & t-stat. & $\beta_{1}$ & Prediction & Prob \\
\hline Fit & 1.463 & 5.758 & + & 0.152 & 27.089 & 26.14 & + & $0.00^{* *}$ \\
\hline Misfit & 41.01 & 27.8 & - & 0.000 & 38.84 & 26.809 & - & 0.000 \\
\hline \multirow[b]{2}{*}{ Group. } & \multicolumn{5}{|c|}{ Internal Process Performance } & \multicolumn{3}{|c|}{ Learning and Growth Performance } \\
\hline & t-stat. & $\beta_{1}$ & Prediction & Prob & t-stat. & $\beta_{1}$ & Prediction & Prob \\
\hline Fit & 29.64 & 26.12 & + & $0.00^{* *}$ & 30.29 & 26.94 & + & $0.00 * *$ \\
\hline Misfit & 42.21 & 27.82 & - & 0.00 & 36.35 & & - & .000 \\
\hline
\end{tabular}


Result of Testing the Concept of The Congruency Hypothesis.

This study also generates fit models based on the value of fit for subsystem elements as presented in Table 6. Based on the figure, this study has found an empirical evidence that: when the subsystems are in a fit condition, the configuration to be formed is a straight or almost straight line (Burrel and Morgan, 1977). The condition illustrates that the elements of the subsystems are at the same or almost the same level, means that one subsystem is able to support the functioning of other subsystems effectively and efficiently. Meanwhile, the value of contingent fit for business units in group misfit Low Cost that consisting of 3 (three) subsystem, configurations are presented in Table 7 .

Table 5. Fit Model and Value of Contingent Fit

\begin{tabular}{|c|c|c|c|c|}
\hline Group & $\begin{array}{l}\text { Number of } \\
\text { Business Units }\end{array}$ & \multicolumn{3}{|c|}{ Fit Model and the Score of Every Element of Subsystem } \\
\hline $\begin{array}{l}\text { Fit Low } \\
\text { Cost }\end{array}$ & 17 & $\begin{array}{l}\text { Strategy Low Cos } \\
\text { Score: } 1,86^{*}\end{array}$ & $\begin{array}{l}\text { MAS Traditional } \\
\text { Score: } 1,6^{*}\end{array}$ & $\begin{array}{l}\text { ITS Automation } \\
\text { Score: } 1,38^{*}\end{array}$ \\
\hline $\begin{array}{l}\text { Fit } \\
\text { Differen- } \\
\text { tiation }\end{array}$ & 20 & $\begin{array}{l}\text { Strategy Differentiation } \\
\text { Score: } 4,29^{* *}\end{array}$ & $\begin{array}{l}\text { MAS Strategic } \\
\text { Score: } 4,22^{* *}\end{array}$ & $\begin{array}{l}\text { ITS Enabler } \\
\text { Score: } 4,44^{* *}\end{array}$ \\
\hline
\end{tabular}

* : The mean score of a strategy, MAS, and ITS for Group Fit Low Cost

**: The mean score of strategy, MAS and ITS for Group Fit Differentiation.

From the table 5, the concept of "the congruency hypothesis" can be described in the figure 6 .

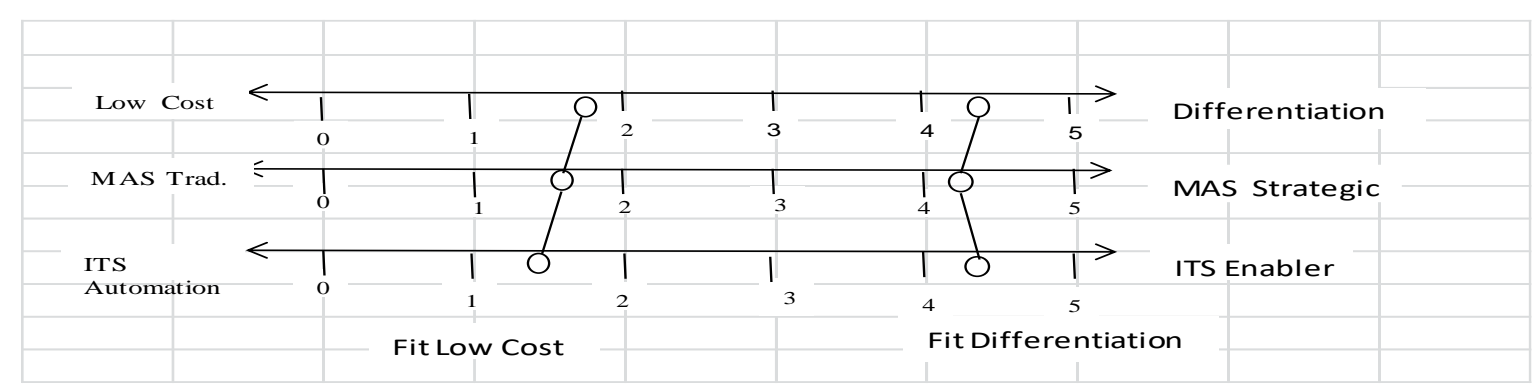

Figure 6. Configuration Of Fit

Table 6. Misfit Model and Contingent Misfit Value of Low Cost Business Units

\begin{tabular}{|c|c|c|c|c|}
\hline Group & $\begin{array}{l}\mathrm{NO} \\
\text { of } \\
\text { Business }\end{array}$ & \multicolumn{3}{|c|}{ Fit Model and the Score of Every Element of Subsystem } \\
\hline $\begin{array}{l}\text { Misfit LC } \\
\text { Configuration } 1\end{array}$ & 8 & $\begin{array}{l}\text { Strategy Low Cost } \\
\text { Score: } 2^{*}\end{array}$ & $\begin{array}{l}\text { MAS Traditional } \\
\text { Score: } 1,7^{*}\end{array}$ & $\begin{array}{l}\text { ITS Enabler } \\
\text { Score: } 4,43^{*}\end{array}$ \\
\hline Misfit LC & & & & \\
\hline Configuration 2 & 6 & $\begin{array}{l}\text { Strategy Low Cost } \\
\text { Score:1,57** }\end{array}$ & $\begin{array}{l}\text { MAS Strategic } \\
\text { Score: } 4,13^{* *}\end{array}$ & $\begin{array}{l}\text { ITS Enabler } \\
\text { Score: } 4,7^{* *}\end{array}$ \\
\hline $\begin{array}{l}\text { Misfit LC } \\
\text { Configuration } 3\end{array}$ & 7 & $\begin{array}{l}\text { Strategy LC } \\
\text { Score: } 1,94^{* * *}\end{array}$ & $\begin{array}{l}\text { MAS Strategic } \\
\text { Score: } 3,95^{\star * *}\end{array}$ & $\begin{array}{l}\text { ITS Automation } \\
\text { Score: } 1,57^{* * *}\end{array}$ \\
\hline
\end{tabular}

* The mean score of a strategy, MAS, and ITS of 8 business units in Group Misfit Low Cost

** The mean score of strategy, MAS and ITS of 6 business units in Group Misfit Low Cost

*** The mean score of strategy, MAS and ITS of 7 business units in Group Misfit Low Cost 


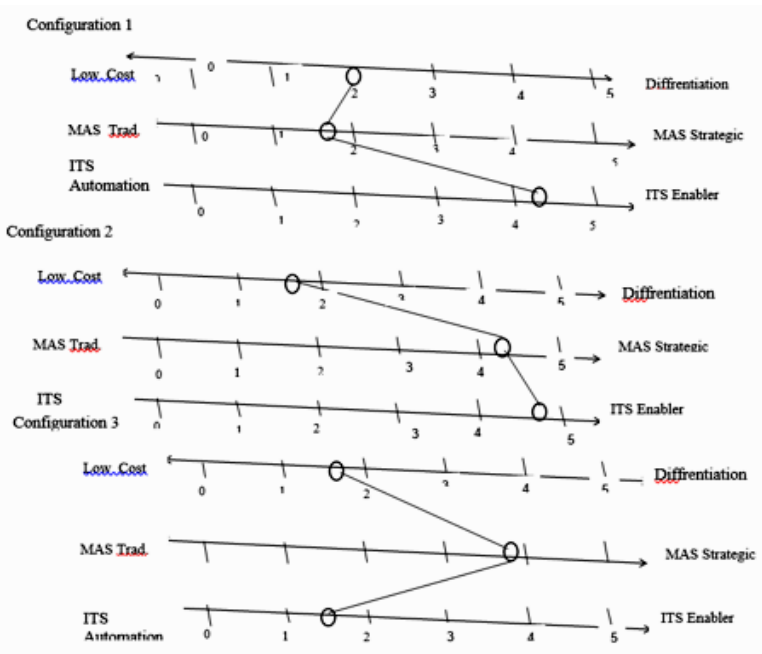

The three forms of the configuration shown in Figure 7. Misfit in the subsystem indicated by the line which is not straight. From the first configuration can be seen that the use of ITS is too "sophisticated" and this condition could potentially generate idle capacity which could further lead to inefficiency. While, the value of the business units within misfit misfit group differentiation are presented in the table 8 .

Figure 7. Misfit Low Cost Configuration

Table 8. Misfit Model and Contingent Misfit Value of Differemtiation Business Units

\begin{tabular}{|c|c|c|c|c|}
\hline Group & $\begin{array}{l}\text { Num } \\
\text { ber of } \\
\text { Busi } \\
\text { ness } \\
\text { Units }\end{array}$ & \multicolumn{3}{|c|}{ Fit Model and the Score of Every Element of Subsystem } \\
\hline $\begin{array}{c}\text { Misfit } \\
\text { Differentiation } \\
\text { Configuration } 1\end{array}$ & 14 & $\begin{array}{l}\text { Strategy } \\
\text { Differentiation } \\
\text { Score: } 4.0^{*}\end{array}$ & $\begin{array}{l}\text { MAS } \\
\text { Traditional } \\
\text { Score: } 1,8^{*}\end{array}$ & $\begin{array}{l}\text { ITS Automation } \\
\text { Skor: } 1,37^{*}\end{array}$ \\
\hline $\begin{array}{c}\text { Misfit } \\
\text { Differentiation } \\
\text { Configuration } 2\end{array}$ & 10 & $\begin{array}{l}\text { Strategy } \\
\text { Differentiation } \\
\text { Skor: } 4,38^{* *}\end{array}$ & $\begin{array}{l}\text { MAS Strategic } \\
\text { Score: } 4,2^{* *}\end{array}$ & $\begin{array}{l}\text { ITS Automation } \\
\text { Score: } 1,34^{* *}\end{array}$ \\
\hline $\begin{array}{c}\text { Misfit } \\
\text { Differentiation } \\
\text { Configuration } 3\end{array}$ & 8 & $\begin{array}{l}\text { Strategy } \\
\text { Differentiation } \\
\text { Score: } 4,1^{* * *}\end{array}$ & $\begin{array}{l}\text { MAS } \\
\text { Traditional } \\
\text { Score: } 1,37^{* * *}\end{array}$ & $\begin{array}{l}\text { ITS Enabler } \\
\text { Score: } 4,8 * * *\end{array}$ \\
\hline
\end{tabular}

* The mean score of a strategy, MAS, and ITS of 8 business units in Group Misfit Differentiation

** The mean score of strategy, MAS and ITS of 6 business units in Group Misfit Differentiation

*** The mean score of strategy, MAS and ITS of 7 business units in Group Misfit Differentiation

The formed of configuration is presented in Figure 8. The first configuration is the use of differentiation strategies that are not supported by sufficient MAS and ITS. In the second configuration, ITS used tend to be "outdated" and thus potentially "inadequate" in supporting of MAS practices which in turn can lead to ineffectiveness of MAS asan information provider for the management, quickly and accurately. While in the third configuration, the use of MAS whic is inadequate although it having been backed up by a sophisticated ITS. This can lead to less optimal of the implementation of differentiation strategy. 


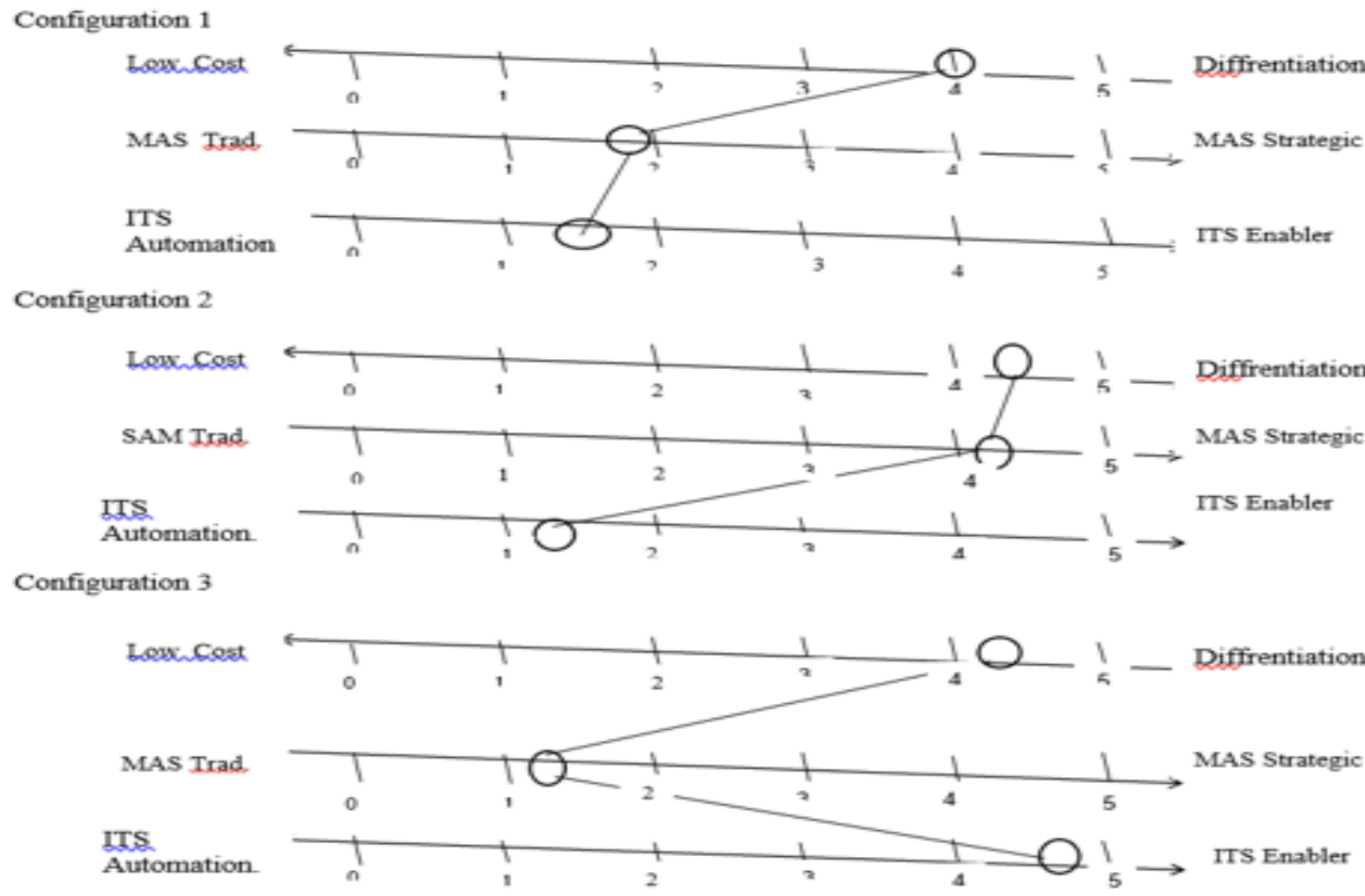

Figure 8. Misfit differentiation strategy Configuration

\section{DISCUSSION}

The results of this study is: Fit has an influence on the performance of customer, internal process, and learning / growth at business units in the group Fit. Below is the discussion of the results for the business units in the group Fit Low Cost and Differentiation.

\section{The influence of Fit on the Growth / Learning Performance}

The performance of Growth/Learning is closely related to human resources (HR) and information technology systems in a business unit. For business units that implement a differentiation strategy, the achievement of learning / growth performance is very important, therefore the fit between Human Resources and Information Resources with strategy is also important (Kaplan and Norton, 2004: 247). The study provides empirical evidence that for group Fit Differentiation, fit have influence on learning/growth performance, which include: employee benefits, employee productivity and the the ability of employees to operate IT. Analysis of thi results is: management of the business unit has been able to align the most important intangible assets, HR and IT with the differentiation strategy. MAS that is practiced is also able to "serve" the employees an adequate information so that differentiation strategy can be implemented properly. The next impact is increased employee productivity, which in turn will have an impact on improving employee satisfaction.

\section{The influence of Fit on the Internal Process Per- formance}

This study obtain empirical evidence that the Fit has an influence on the achievement of the performance of internal processes in the business units in the group Fit. For the business units implements a differentiation strategy, internal process management means managing the overall process that includes: operations management, customer management, regulatory and social innovation, and the main concern should be given by the management to innovation (Kaplan and Norton, 2004: 326). Therefore, the differentiation strategy requires support of MAS that provides information both financial and non-financial as well as ITS which is able to collect, process and store data / information quickly and accurately. As for the business units that implement low-cost strategy, the more important thing to do is to ensure the achievement of efficiencies, with or without Fit. This analysis is in accordance with the information provided by one of the 
production staff of a business unit as the sample of this study that "efficiency is the soul for the company".

\section{The influence of Fit on the Customer Perfor-} mance.

Managing customer activity include: "select customers, acquire customers, retain customers and grow relationships with customers" (Kaplan and Norton, 2004:107). There is a big responsibility of the marketing department because of higher environmental uncertainty which in turn led to an increased uncertainty of the task, even, it higher compared with of other parts/departments. Therefore, marketing executives need more extensive, timely and accurate management accounting system (Mia and Chenhall, 1994). And, this condition has been achieved by business units which includes as a sample in this research.

\section{The Influence of Fit on Financial Performance}

The empirical evidence obtained from this study is: fit does not effects on the financial performance. Analysis of these results is: preparation of financial statements by companies in Indonesia in general only to meet regulatory requirements/ legislation. As noted by Diga and Yunus (1997: 299230), in Indonesia, management accounting system is generally used to provide information about the cost of inventory based on full costing and for the balance sheet preparation. While, the financial performance tested in this study are: Return on Investment (ROI) and profitability, both of which require information on earnings presented in the Income Statement. Based on research by Feliana (2012), accounting information generated by companies in Indonesia strongly influenced by the intervention of the owner that caused the management does not fully meet the timeliness in providing income information for users of financial statements. As a result, the target in the realization reports can not be compared so that the information the targets may not be available. As a further consequence, there is a possibility, respondents' answers with regard to the achievement of financial performance targets is also not based on real achievement.

\section{The Influence of Contingent Misfit on Performance}

For business units in group misfit, all coefficients obtained do not match with the prediction. With this result it can be concluded that this study has not proved that misfit negatively affect the performance. This result can be perceived: although subsystems in business unit in misfit conditions but the interdependence of the subsystems has occurred and this could potentially generate high performance. This is consistent with the conclusions of Hayes (1977) which shows that the interde-pendencies with three dimensions: reliability, cooperation and flexibility positively affects the performance of the business unit.

\section{The Proof of The Congruency Hypothesis}

This study also obtain empirical evidence, when business unit is in fit condition, then the line formed in the congruence hypothesis graph is a straight or almost straight line. For these business units, contingent fit has positive influence on performance. While the business unit that is in a misfit condition, the line formed in the chart is not straight. As explained earlier, in this study the coefficient obtained does not match the prediction. This means, this study has not yet proved that misfits have a negative effect on performance.

\section{CONCLUSION AND SUGGESTION}

Fit has a positive and significant effect on performance of customer, internal process, and Learning / Growth in group Fit. These results support the Contingency Theory. This study also prduce empirical evidence that $\beta$ (coefficients) of regression is positive for the entire performance (except financial performance) for Fit Low Cost and Differentiation business units. Although not significant, but this result is in accordance with the prediction, which means it supports the Contingency Theory.

In this study, the results obtained with regard to the influence of misfit on the performance of financial, customer, internal processes and learning/growth is inconsistent for business unit in group Misfit Low Cost and Differentiation. Besides, $\beta$ (coefficients) does not match the prediction. This means, this study has not yet proved that misfits have a negative effect on performance.

This study also proved the model of fit as formulated by Burrell and Morgan (1977) within the concept of "The congruency Hypotheses". In accordance with the contingency theory, fit will form a straight line (almost straight), which means subsystems in business unit are at the same level. For these business units, contingent fit has positive influence on performance. Howecer, for business unit that is in a misfit condition, the line formed in 
the chart is not straight, and proved that for these business units, contingent misfit has no effect on performance.

Limitation of this study was primarily related to the amount of data obtained. Therefore, future research needs to seek additional number of data acquisition. In addition, with regard to the use of information technology systems, this study did not consider whether ITS is decentralized or centralized. Where the use of the ITS decentralized, business unit management has full authority in selecting and using of ITS. There is a possibility of a different result when the ITS is centralized where various decisions relating to the use of ITS is on the management of the parent company.

\section{REFERENCES}

Atkins, MH, (1994), Information Technology and Information Systems Perspectives on Business Strategies, Journal of Strategic Information Systems, 3 (2), pp.123-135.

Baines, Annete and Kim Langfield-Smith, (2003), Antecedents to Management Accounting Change: a Structural Equation Approach, Accounting Organizations and Society, 28: 675698.

Bhimani, Alnoor, (2006), Management Accounting and Digitization, in Contemporary Issues in Management Accounting, Edited by Alnoor Bhimani, New York, USA, Oxford University Press: 70-91.

Burrel, Gibson and Gareth Morgan, (1979), Sociological Paradigms and Organisational Analysis, Vermont, USA, Ashgate Publishing Company.

Chenhall, Robert H, (2007), Theorising Contingencies in Management Control Systems Research In Handbook of Management Accounting Research, edited by Christopher S Chapman, Anthony G Hopwood, and Michael D. Shields Volume 1, Oxford, UK, Elsevier: 163205.

Chenhall, Robert H, (2003), Management Control Systems Design Within Its Organizational Context: Findings from Contingency-Based Research and Directions for the Future, Accounting, Organizations and Society, 28: 127168.

Dechow Niels, Markus Granlund and Jan Mouritsen, (2007), Management Control of the Complex Organization: Relationships Between Management Accounting and Information Technology, in Handbook of Management Accounting Research, Edited by Christo- pher S. Chapman, Anthony G. Hopwood and Michael D. Shields, Kidlington, Oxford, Elsevier Ltd: 625-640.

Diga, Joselito and Hadori Yunus, (1997), Accouting In Indonesia, in Accounting in the Asia-Pasific Region, edited by Nabil Baydoun, Akira Nishimura and Roger Willet, Singapore, John Wiley \& Sons (Asia) Pte, Ltd.

Donaldson, Lex, (2001), The Contingency Theory of Organizations, New Delhi, India Sage Publication, Inc.

Drazin, Robert and Andrew Van de Ven, (1985), Alternative Forms of Fit in Contingency Theory, Administrative Science Quarterly, 30: 514539.

J. Donald WarrenJr., Kevin C. Moffitt, and Paul Byrnes (2015) How Big Data Will Change Accounting. Accounting Horizons: June 2015, Vol. 29(2): 397-407.

Duh, Rong-Ruey, Chee W Chow and Hue iling Chen, (2006), Strategy, IT Applications for Planning and Control, and Firm Performance: The Impact of Impediments to IT Implementation, Information $\mathcal{E}$ Management, 43: 939-949.

Feliana, Yie Ke, (2012), Peran Transaksi Dengan Pihak Yang Memiliki Hubungan Istimewa Sebagai Mediasi Pengaruh Struktur Kepemilikan Terhadap Kualitas Informasi Akuntansi Keuangan (The Role of Transactions With Related Parties As Mediation on the Influence of Ownership Structure Against Quality Accounting Information), Dissertation, Faculty of Economic and Business, University of Airlangga, Surabaya,

Ferdinand, Augusty, (2006), Metode Penelitian Manajemen (Management Research Methods), Second edition, Semarang, Diponegoro University Publishing Agency.

Gerdin, Jonas and Jan Greve, (2004), Forms of Contingency Fit in Management Accounting Research-A Critical Review, Accounting, Organizations and Society, 29: 303-326.

Hair, Joseph R, et al. (2010), Multivariate Data Analysis, A Global Perspective, New Jersey, Pearson Education Inc.

Hayes, David C, (1977), The Contingency Theory of Managerial Accounting, The Accounting Review, Vol. L11. No. 1: 22-39.

Jogiyanto, H., (2005), Sistem Informasi Strategik Untuk Keunggulan Kompetitif (Strategic Information System For Competitive Advantage), Bandung, Andi Publisher.

Jogiyanto, H., (2003), Sistem Teknologi Informasi, 
Pendekatan Terintegrasi: Konsep Dasar, Teknologi, Aplikasi, Pengembangan dan Pengelolaan, (Information Technology System, Integrated Approach: Basic Concepts, Technology, Applications, Development and Management), Bandung, Penerbit Andi.

Hemmatfar, M., (2010), Competitive Advantages and Strategic Information Systems, International Journal of Business and Management Vol. 5(7): 158-169.

Hoque, Zahirul, (2004), A Contingency Model of the Association Between Strategy, Environmental Uncertainty and Performance Measurement: Impact on Organizational Performance, International Business Review, Vol.13: 485-502.

Hyvonen, Johanna, (2008), Linking Management Accounting and Control Systems, Strategy, Information Technology, Manufacturing Technology and Organizational Performance of the Firm in Contingency Framework,

Ireland, Duane, Robert E Hoskison and Michael A Hitt, (2009), The Management of Strategy, Concepts and Cases, Mason USA, South Western Cengage Learning.

Jermias, Johnny and Lindawati Gani, (2005), Ownership Structure, Contingent-Fit, and Business-Unit Performance: A Research model and Empirical Evidence, The International Journal of Accounting, 40; 65-85.

Jermias, Johnny and Lindawati Gani, (2004), Integrating Business Strategy, Organizational Configurations and Management Accounting Systems with Business Unit Effectiveness: a Fitness Landscape Approach, Management Accounting Research, 15: 179-200.

Jermias, Johnny and Lindawati Gani, (2003), Sistem Teknologi Informasi, Pendekatan Terintegrasi: Konsep Dasar, Teknologi, Aplikasi, Pengembangan dan Pengelolaan, Bandung, Penerbit Andi.

Kaplan, Robert S and David P Norton, (2004), Strategy Maps, Converting Intangible Assets into Tangible Outcomes, Boston, Harvard Business School Publishing Corporation.

Kaplan, Robert S and David P Norton, (1996), The Balanced Scorecard, President and Fellows of Harvard College.

Kholeif, Ahmad O, Magdy G Abdel Kader and Michael J Scherer, (2008), Enterprise Resource Planning Implementation and Management Accounting Change in a Transitional Country, New York, Palgrave Macmillan.

Malmi, Teemu and MikkoSandelin, (2016), Man- agement control effectiveness and strategy: An empirical analysis of packages and systems, Accounting, Organizations and Society. Volume 51, May: 12-28

Ministry of Industry, (2011), Directory of Big Industry in East Java in 2010.

Miklos A. Vasarhelyi, Alexander Kogan, and Brad M. Tuttle (2015) Big Data in Accounting: An Overview. Accounting Horizons: June 2015, Vol. 29(2):. 381-396.

Kurniawan, Edy, (2011), Enterprise Resource Planning, www.research.amikom.ac.id/

Langfield-Smith, Kim, (2006), Understanding Management Control Systems and Strategy, In Contemporary Issues in Management Accounting, edited by Alnoor Bhimani, New York, USA, Oxford University Press, pp.243-265.

Langfield-Smith, Kim, (2007), A Review of Quantitative Research in Management Control System and Strategy, in Handbook of Management Accounting Research, Edited by Chapman, Hopwood and Shields, Elsivier Ltd, pp.753783.

Luftman, Jerry N, Raymond Papp and Tom Brier,1999, Enablers and Inhibitors of BusinessIT Alignment, Communications of AIS, Vol.1(11): 1-33.

Luftman, Jerry and Tal Ben-Zvi, (2011), Key Issues for IT Executives 2011: Cautious Optimism in Uncertain Economic Times, MIS Quarterly Executives, Vol. 10(1).

Mia, Lokman and Robert H Chenhall, (1994), The Usefulness of Management Accounting Systems, Functional Differentiation and Managerial Effectiveness, Accounting, Organization and Society, Vol.19(1): 113.

Morton, Neil A and Qing $\mathrm{Hu}$, (2008), Implications of the Fit Between Organizational Structure and ERP: A Structural Contingency Theory Perspective, International Journal of Information Management, 28: 391-402.

Nishimura, Akira, (2005), Fundemental Features and Perspectives of Management Accounting in Asia, In Management Accounting in Asia, edited by Akira Nishimura and Roger Willet, Singapore, Thomson Learning.

Otley, David T, (1980), The Contingency Theory of Management Accounting Achievement and Prognosis, Accounting, Organizations and Society. Vol. 5(4): 413-428.

Pedro, Soto-Acosta, Simona Popa, Isabel MartinezConesa, (2018) Information technology, knowledge management and environmental 
dynamism as drivers of innovation ambidexterity: a study in SMEs, Journal of Knowledge Management.

Pervan, Ivica and Dropulic. Ivana (2019). The Impact of Integrated Information Systems on Management Accounting: Case of Crotia. Journal of Contemporary Management Issues. Management, Vol. 24 (1): 21-38

Porter, Michael E, (1993), Strategi, Bersaing: Teknik Menganalisis Industri dan Pesaing, terjemahan oleh Agus Maulana, Jakarta, Penerbit Erlangga.

Sekaran, Uma, (2003), Research Methods For Business, A Skill Building Approach, New York, John Wiley \& Sons.

Turban, Efraim and Linda Volonino, (2010), Information Technology for Management, Improving Performance in the Digital Economy, seventh edition, New York USA, John Wiley \& Sons.
Venkatraman, N, (1994), IT-Enabled Business Transformation: From Automation to Business Scope Redefinition, Sloan Management Review; Winter Vol. 35(2): 73-87.

www.bps.go.id (Central Bureau of Statistics)

www.microsite.metronews.com, 2014, Industri Manufaktur Melek Teknologi (Manufacturing Industry Technology Literacy).

Zuhroh, Diana, (2015), The Fit of Competitive Strategies, Management Accounting Systems, and Information Technology Systems, And Its Effect On Business Unit Performances, APMAA Journal, Vol.2(10):21-56. 